\title{
THE NEED FOR INTERNATIONAL COOPERATION IN CRIMINAL MATTERS: CASE OF MADAGASCAR
}

\author{
Saida Tongalaza \\ International Office Parahyangan Catholic University \\ J1. Ciumbuleuit 94 Bandung 40141 \\ Email: princessesaida@gmail.com
}

\begin{abstract}
Abstrak
Kerjasama dalam ranah hukum pidana menjadi alat atau sarana yang memperbolehkan bagi penegak hukum di suatu negara untuk mengajukan banding terhadap negara lain. Keadaan ini harus dipandang sebagai upaya untuk mengikatkan diri dengan tidak dimaksudkan turut campur terhadap proses peradilan pidana. Perbuatan kriminal dalam ruang lingkup internasional dan bentuk lain dari kejahatan trannasional menjadi pemicu dilaksanakannya sistem peradilan pidana ini, baik tingkat regional maupun global. Madagaskar sama halnya dengan negara lain secara aktif turut serta untuk mengembangkan sistem ini, akan tetapi yang menjadi pertimbangan apakah tindakan ini dapat dibatasi atau tidak?. Lain kata apakah tindakan ini dapat dilakukan di bawah Konvensi Internasional?. Jawaban atas pertanyaan ini memerlukan penetapan bagianbagian dari kerjasama yang diperbolehkan untuk dilakukan. Lain kata pernyataan turut serta dalam ranah kerjasama dapat dicapai melalui permintaan agar dipenuhinya keadaan tersebut. tulisan ini ditujukan untuk mengkaji kerjasama internasional antara Madagascar sebagai sebuah negara berdaulat dengan negara-negara lain dalam memerangi tindak pidana. Tulisan ini menggunakan metode yuridis normatif melalui penelitian kepustakaan (library research). Madagascar memiliki komitmen dalam setiap bidang hukum yang berkaitan dengan kerjasama internasional yang saling mengikat dalam Judicial Cooperation Agreement, demi pencapaian kebutuhan akan keadilan. Kerjasama ini dapat berjalan secara efektif, bila setiap negara memiliki resolusi untuk memerangi kejahatan melalui suatu kerjasama.
\end{abstract}

Kata kunci: kejahatan internasional, kerjasama, pihak yang berwenang

\begin{abstract}
The cooperation in criminal matters is a collaboration tool allowing a criminal authority of a country to appeal to a foreign authority for lute against offenses has international character or performance measures within the scope of the criminal proceedings. The internationalization of criminality and other forms of transnational crime were responsible for the implementation of this system at regional and global level. Like all other countries of the world, Madagascar is actively involved in the development of this international cooperation. But one wonders whether the offenses for which such assistance is applied are limited or not. In other words, is that such cooperation is limited to offenses under the International Convention? The answer to these questions requires the determination of the areas on which cooperation can take place. In other words, the statement of offense to the achievement of which assistance or more precisely corporation may be requested. The main Issue on this paper purposing international cooporation between Madagascar as sovereignty state with other states to fight criminal matters. This paper use juridical normative with library research methodology. Madagascar like any other country
\end{abstract}


in the world has signed since its independence, a Judicial Cooperation Agreement to deal with any kind of legal constraint internationally. In fact, the cooperation is a strategy that aims to curb impunity. Therefore: the prerequisite for the establishment of justice. But to achieve effective cooperation, it is necessary that each country shows its resolution to fight together against crime through cooperation.

Key words: international crime, cooperation, competent authority

\section{Introduction}

In the world we live in the global mobility has intensified, the increasingly close communication between states but also between individuals, the globalization of almost all human activities and the increasing mobility of people and goods, and the increased sophistication of the means employed by the large international crime to go unpunished, it becomes easier for offenders to go abroad after committing an offense. Using modern means of communication, such as the Internet, can also commit crimes in another country without the physical presence is required in it. Moreover, for several years, the phenomenon of organized crime has changed in scale and has become one of the most threatening vectors for the stability of a large number of states.

The application of the law against the offender in the international field is very complex. This complexity can be explained by the principle that every state has sovereignty over its territory. In other words, under the principle of territorial sovereignty, State's home is his castle, that is to say it has exclusive or monopoly jurisdiction within its borders where no State may exercise its authority. This plenary jurisdiction arises both politically, economically and as a jurisdictional matter. In this regard, the problem arises in that it is difficult to prosecute a person who commits an offense or a crime in one country and then fled in another sovereign state if these two states are not bound in a single agreement on cooperation in criminal matters.

Moreover, only the International Criminal Court (ICC) may issue an international arrest warrant against anyone suspected even if the requested State and the requesting State are not related in any extradition cooperation agreement. This is therefore called the principle of extraterritoriality. "International support repressive procedure by which a State, called requested State agrees to deliver an offender who is on the territory of another State, the applicant state, so that the latter can judge this individual, or if he already been condemned to make him serve his sentence." Therefore, this principle is a guarantee impunity for criminals. Also, international criminal organizations and other criminals, benefit most voids and contradictions resulting normative disparities between states.

1 Raymond Guillien, Jean Vincent, Serge Guinchard, Gabriel Montagnier, Lexique des termes juridiques (ed. Dalloz), 16th Edition, Papier, Toulouse, 2007, page 429. 
Faced with this situation, it was necessary to seek remedies this problem to escape justice. And on eof the solutions was the establishment of a common legal structure as part of mutual assistance and cooperation in criminal matters to regional and global scale. Thus, the idea of a comprehensive international instrument in the context of a mutual International Legal has a more important role in the fight against any kind of international crime and transnational organized crime. This international practice, is a kind of cooperation between the competent authorities of two or more states to overcome differences in national legislation and to facilitate judicial relations between states, such as the arrest of the suspect, the search for information, citation of witnesses, the fulfillment of a taking of evidence, or evidence gathering related to interrogation investigation, seizure and confiscation of illicit proceeds of crime or even the delivery of the offender. It is commonly designated by the term "extradition". This is the procedure which a State shall,

1. either a person within its territory, another State that it has made the request to judge that person or apply the sentence was pronounced by its courts against him;

2. either a fugitive, regardless of its agreement, by the authorities of the receiving State, the authorities of a third country to allow the criminal prosecution or executing a sentence imposed.

On the occasion of the World Ministerial Conference on Organized TransnationalCrime, the idea of a comprehensive international convention against transnational organized crime was launched for the first time in 1994 in the Declaration of Naples ${ }^{2}$. Madagascar for its part, is working with other foreign states in the fight against all forms of transnational criminal offending, that is to say, cooperate in the exchange of information, investigation and procedure the one hand, and the fight against impunity of the author on the other. Agreements have been ratified to understand the various facets of transnational crime are further complicated by globalization and the development of technologies and means of communications. Indeed, Madagascar has ratified various international conventions and treaties on a bilateral and multilateral character by which it has committed to lend his legal assistance in criminal matters in order to face various forms of international crime.

It should be noted, moreover, that to give effect to the objectives of these instruments, $\mathrm{He}$ proceeded to the reform of national legislation and putting in place appropriate structures to fight against crimes such as: the fight against trafficking in narcotic law No. 97039 of 4 September 1997 on the fight against and repression of drug trafficking, psychotropic substances, precursors. As such, it creates an inter-ministerial committee

2 World Ministerial Conference on Organized Transnational Crime, Report Of The Ad Hoc Committee On The Elaboration Of A Convention Against Transnational Organized Crime On The Work Of Its First To Eleventh Sessions, 1994. 
to coordinate the fight against drugs. This law also criminalizes money laundering crimes. Then Madagascar, complementing international standards, adopted the Law 2004-020 of August 19, 2004 for laundering of proceeds from illegal activities, screening, confiscation and international cooperation in crime produced by the mutual legal assistance and extradition. In addition, there are, in Madagascar a Central National Interpol Bureau, which contributes to the exchange of information between Madagascar and its partners in the framework of ICPO or International Criminal Police Organization. Finally, there is also setting up independent bodies, as BIANCO 3 under the law 2004-030 of 9 September 2004 for the implementation of the strategy for preventing the suppression of acts of corruption and SAMIFIN ${ }^{4}$ is currently operational since July 18, 2008 which is a neighboring institution BIANCO.

In a word, international cooperation in criminal matters aimed essentially one hand, prevention and repression of various forms of criminal offending rampant everywhere, secondly, assist and help member countries the exchange of information and prosecution against the suspects. Moreover, now where international crimes are developing, at a time when the planet is increasingly exposed to new forms of crime such as organized crimes, economic and financial delinquency, offenses against the person, which include sexual abuse and trafficking of organs, breaches of regulation and public policy, trafficking of drugs and finally terrorism, which no country in the world can claim to not be affected by this scourge, it is appropriate to study more deeply the international cooperation in criminal matters : the case in Madagascar.

This topic is framed in the field of criminal offenses of an international character which Madagascar is involved, in other words, the cooperation of Madagascar with othercountries for the control and prevention of organized crime and other international crimes. This work aims to answer the following questions: in what areas can we apply this cooperation? What are the mechanisms to be followed for the implementation of the cooperation?

So, to do this, it is necessary to understand this work in two ways: The application fields of international cooperation in criminal matters and The authorities involved. The main Issue on this paper purposing international cooporation between Madagascar as souvereignty state with other states to fight criminal matters, that being part of extraordinary drime in several

3 BIANCO: Bureau Indépendant Anti-Corruption is the independent anti-corruption office in Madagascar. It was founded in 2004 to implement a national anti-corruption strategy through the application of law and preventative measures against corruption, as well as education of the public.

4 Samifin: Sampan-draharaha Malagasy Iadianaamin'ny Famotsiam-bola; is the Malagasy Financial Intelligence Services, and acts as an independent body in Madagascar. Which details the tracking and confiscation of illegal products, and Decree 2007-510 (June 4, 2007), which details the creation, organization, and operation of the organization. Its objectives are to clean up the financial sector in Madagascar and combat transnational illegal operations. 
criminal case, such as corruption and money laundring. This paper use juridical normative with library research methodology, with statue approach based on Madagascar law, United Nation Convention, Convention Agreement etc.

\section{Analyze}

\section{A. The Application Fields of International Cooperation in Criminal Matters}

\section{Corruption to laundering}

The Corruption and laundering of proceeds of crime are among the areas covered by the UN Convention pursuant to Articles 6 and 8 . So for more information on these crimes, it is necessary to examine their respective points.

Nowadays, corruption is a topic that is discussed openly in most countries, there are few who claim not to suffer. The corrupt practices and organized crime are closely related. For, corruption facilitates illicit activities and obstructs law enforcement. Therefore, the fight against corruption is therefore integral part of the fight against organized crime. The concept of corruption is defined by Article 8 paragraph 1 of the Convention United Nations as the fact, by a person holding public authority, discharging a public service mission or holding elected public office, solicit or accept, in particular, the offering to that person directly or indirectly, offers, promises, gifts or any benefits to it or refrain from acting in his official capacity. In other words, corruption is a reward or any other unlawful behavior towards people with responsibilities in the public or private sector that contrary to the responsibilities that they have under their status as agent of the state, of private sector employee, independent agent or other report of this nature and aims to provide undue advantages of any kind for themselves or for others.

Whatever its form, the corruption always involves an exchange; it assumes that there is, firstly, an offer (the bribe), and the other, a request (the beneficiary). There are different degrees of corruption. Some observers distinguish between "small" corruption and "big" corruption ${ }^{5}$.The first relates generally to the payment of small sums to government officials of lower rank, in order to "make things" or bypass certain bureaucratic obstacles. On a larger scale is for large multinational companies, paying thousands or even millions of dollars to government officials or politicians to obtain lucrative commercial contracts. This distinction does not mean that some forms of corruption are worse than others. Because even if it is of lesser degree, it can have very serious consequences. Moreover, corruption can exist in the political and economic institutions of one country, this is no longer a small group of dishonest individuals is involved, but

5 Djillali Hadjadj, Law, Transparency International, 2002, books.google.fr/books. 
institutional corruption This phenomenon is growing, especially when institutions are in a weak position. It is closely related to poor governance.

This corruption is particularly prevalent in the absence of adequate legislative control means, judicial bodies or autonomous control bodies. Faced with these different forms of corruption, many initiatives have been taken in order to fight against this scourge, national, regional as well as international. These include, at national level, the Government's initiative by the establishment of an autonomous institution for the fight against corruption BIANCO under Law No.2004-030of9 September 2004and the recent establishment of SAMIFIN. Regionally, the convention of the nations of the African Union on the fight against corruption and the $\mathrm{SADC}^{6}$ Protocol against Corruption, finally, on the international level, UN Conventions against Transnational Organized Crime and the $\mathrm{OECD}^{7}$

Convention on the fight against the bribery of foreign public officials in international business transactions. The reason that the international organization has mobilized to fight against Corruption is simple, because it respects no borders, admits no economic distinction and introduced in all forms of government. Ultimately, no country can afford the social, entailed political and economic corruption. It undermines trust in political institutions and encourages despise the rule of law; it distorts the allocation of resources and harms competition on the markets; and has a negative impact on investment, growth and development. In addition, corruption has an extremely high cost to the poorer classes of the population to the extent that it prohibits them access to essential basic services. It is now necessary to ask how obvious then that offense. To this question, it is essential to understand the multiple aspects or more specifically the various forms of corruption.

\section{a. The various forms of corruption}

It should be noted that corruption exists in two forms: active corruption and passive corruption. But a number of offenses can be assimilated to know: influence peddling, bribery, favoritism, exemption and illegal franchise, taking unfair advantage, prohibited taking up employment, conflict of interest, illicit enrichment

\section{1) Passive corruption}

This form of corruption, our definition is summarized on two areas: public and private sector. In the first case, it is made to any public official or elected solicit or to accept a user unlawful advantage for doing or refrain from

6 Southern African Development Community (SADC) is an inter-governmental organization. Its goal is to further socio-economic cooperation and integration as well as political and security cooperation among 15 southern African states. It complements the role of the African Union.

7 Organization for Economic Co-operation and Development (OECD) is an international economic organization of 34 countries founded in 1961 to stimulate economic progress and world trade. It is a forum of countries describing themselves as committed to democracy and the market economy, providing a platform to compare policy experiences, seeking answers to common problems, identify good practices and coordinate domestic and international policies of its members. 
doing an act of his duties. While the second is the fact for anyone working in the private sector to seek or accept an unlawful advantage for performing or refrain from any act of his duties. Passive corruption is defined as an offense of a public official or employee, to take the initiative unilaterally to demand or claim a benefit of any kind against either of his performance of his work by this definition, so there was passive corruption as soon as the corrupt accepted offer, donation, promise to give it.

\section{2) Active corruption}

This is for any person to offer a public official or an elected unlawful advantage for doing or refrain from doing an act of his duties. The Article 8 of the UN Convention states that each State shall consider adopting legislative measures and other measures to establish as criminal offenses.

In Madagascar, this form of corruption is the subject of section 177.1 of the Criminal Code. That is to say, on the offense, the briber seeks to offer without right, directly or through an intermediary, offers, promises, donation, present or any benefit for a person holding public authority, discharging a public service mission or holding elected public office so that it is doing or forbearing to do any act of his function, mission or mandate; facilitates its function, mission or mandate fulfillment whether this act and abuse his real or supposed influence in order to obtain an authority or a public administration distinctions, jobs, contracts or any other favorable decision. ${ }^{8}$ The same code also provides for active bribery of foreign public officials and officials of public international organizations in article 177.2. Therefore, it is wrong, the promise, offering or giving to a foreign public official or an official of a public international organization, directly or through an intermediary, an undue advantage, for himself or any other person or entity, for him or refrain from acting in the exercise of his official duties, in order to obtain or retain business or other improper advantage in connection with activities international trade.

Corruption can be compared to several other offenses we'll examine a few.

\section{b. Influence peddling}

It can be defined as the act of a person to abuse his real or supposed influence to obtain an authority or public administration, a favorable decision. Giving in to demands or offers and the one who mediates also punished. According to the Malagasy Penal Code specifically in Article 179 paragraph 1 , this offense is made initially by : the fact solicit or accept, directly or through an intermediary, offers, promises, or present any advantages. And these, of course made for an authority or a public administration distinctions, decorations, jobs, contracts or any other favorable decision. Note that influence peddling is equated with corruption, but they

8 Article 177.1 is in Act No.2004-030of09/09/04 of the Malagasy Penal Code. 
differ only on the aims pursued. In terms of influence, the author solicits or approved bids to abuse his real or perceived influence.

Influence peddling can be defined as: "The offense of soliciting or accept offers, donation, promises to abuser of a real or positive influences in order to obtain an authority or public administration, distinctions, employment, steps or any other favorable decision. The fact is more severely depressed when done by a person exercising a public function."

The new object is that influence peddling is not the doing of an act in a person exercising a public function (or private) determined but the exercise by it of its influence to another person. Trading in influence however is a complex form of corruption to the extent that it is not only bilateral (bribe corrupt) but also trilateral in its finality. Alongside the two parties to the act, it is, indeed, a third, depending on which the act was done: it is the public person is expected to adopt a certain behavior. The person exercising the influence is an intermediary in relation to the third actor. The influence peddling is as corrupt as indirect or second degree.

\section{c. The money laundering}

The fight against money laundering is one of the major International issues . This phenomenon does exist in Madagascar. Therefore, it is currently in Madagascar, as in many countries of the world, an essential component of international cooperation. The international strategy against money laundering states that the activities of money laundering as well industrial countries worried that the developing countries. Madagascar, to meet the urgent international cooperation in this regard and to fight against this practice, has recently passed the law against money laundering under the Act 2004-020 of 19 September 2004 and the Decree 2007-510 by the establishment of a financial intelligence unit in the fight against money laundering (SAMIFIN). Thus, to be able to identify these global ills, it is necessary to define them before determining their aspects and their respective links.

Money laundering can be defined in different ways. Despite its many definitions, it is necessary to refer to Article 6 of the UN Convention on the fight against transnational organized crime and Article 1 of Law No. 1a Madagascar 2004-020 of 19 August 2004 on Laundering, Search, confiscation and international cooperation in the proceeds of crime. Thus, according to these texts, it can be defined as the conversion or transfer of property, for the purpose of concealing and disguising the illicit origin or of assisting any person who is involved in the commission of the predicate offense to evade the legal consequences of his actions; concealment or disguise the nature, source, location, disposition, movement or ownership of

9 Raymond Guillien, Lexique des termes Juridiques, 16th Edition, Dalloz, 2007, page 647. 
property. These provisions, it is a process to conceal the criminal origins of capital. It is the process by which the criminal is hiding money by ensuring that the money acquired illegally seem legally owned by introducing it into a regular economic circuit.

That is to say criminal activity is concealed to obscure the illicit origin of the property and allow the author to enjoy legally, to make it grow or finance other activities criminal thereafter. Otherwise The Financial Action Task Force (on Money Laundering) (FATF) briefly defines money laundering as the act to restate these criminal proceeds to disguise their illegal origin in order to legitimize the ill-gotten gains.

Therefore, it should be noted that the purpose of the operation, which usually takes place in several stages, is to believe that capital and assets illegally acquired have a legal source and inserting them into the economy.

It is summed up in investment, that is to say, that dirty money or capital provided by these activities is invested in legal activities. The UN Convention and Malagasy law does not limit the predicate offenses that is to say criminal activity including illegal product is bleached. This agreement includes, in fact all serious offenses. That is why she asks all member countries to strive to expand the money laundering offenses to cover the widest range of predicate offenses ${ }^{10}$

The Money laundering is not a new phenomenon; it is as old as crime itself.
Criminals are always actively sought to conceal the origin of the assets acquired criminally erase all traces of their misdeeds. It is part of financial crime. Most often, it is rooted in marketing narcotic that is to say, in drug trafficking but also in other crimes such weapons trafficking, extortion, embezzlement, prostitution and trafficking, the illegal sale of drugs but also corruption. Laundering to be conducted following a complex process.

\section{d. Bleaching process}

Bleaching is usually done in three phases which are: placement or pre-wash, stacking and recycling or integration.

\section{1) The placement or pre-wash}

The first step is to introduce the funds with illegal origin in the financial system, usually through a financial institution. This can be accomplished by depositing cash into a bank account. Large amounts of cash are split to obtain are smaller and less suspicious, which are then deposited in different offices of the same financial institution. Currency exchange and conversion of small denominations of larger species may occur at this stage. Furthermore, illegal funds may be converted into financial instruments, such as money orders or checks, and commingled with legal funds to divert suspicion.

\section{2) The stack}

This second step is to perform a series of conversions or movements of the funds to distance them from their source. That is to say, 
money laundering occurs after the ill-gotten gains have been introduced into the financial system. And the fund, the title are converted or moved to other institutions, for advantage away from their criminal origins. Funds can then be transferred through the purchase, or the launderer might simply wire the funds through a series of accounts at various banks around the world. In some cases, the launderer might disguise the transfers as payments for goods or services. This enables him to give a legitimate appearance.

\section{3) Recycling or integration}

This third and final stage returns to introduce the amounts laundered in the economy after giving them legitimacy. Indeed, the integration allows the product to reinsert operations, disperse in the economy so that appear as legal profits of official business. Will they be so important, the economic and financial offenses are not the only areas of international cooperation. Indeed, other acts also interested mutual aid.

\section{The other fields}

International cooperation is needed to better fight against acts that often, in addition to being well organized, either personally affects the physical integrity, or freedom. In short: acts that violate fundamental rights such as trafficking of people and torture.

\section{a. Human traffic}

Trafficking in human beings is one of many illegal activities related to organized crimes.
It is an organized criminal phenomenon that affects all countries, because in many countries whether developing or industrialized, criminal groups engaged in trafficking in persons, especially children and women. Internationally, human trafficking is a major source of profits, and help to strengthen and expand the capacity of criminal organizations. Therefore, this criminal practice becomes a hot topic worldwide. Unlike illegal immigration, where people try to emigrate voluntarily by illegal means and are usually free once they arrive at their destination, no traffic is to transport or detain people through coercion, violence or threat of violence. According to the United Nations Convention against transnational organized crime, smuggling refers to facilitating the illegal entry of a person to a country for the purpose of financial gain. By cons, trafficking in human beings includes the movement of a person through coercion, deception or violence for the purpose of exploitation. This activity often includes the sexual exploitation of women and children, but also the traffic of men and women for forced labor or other services associated with debt bondage.

Human trafficking involves the recruitment, transportation, transfer, harboring or receipt of persons, by means of threat or use of force or other forms of coercion, abduction, fraud, deception, abuse of power or of a position of vulnerability or the giving or receiving of payments or benefits to achieve the consent of a person 
having control over another person for the purpose of exploitation. Anyway, exploitation includes, at a minimum, the exploitation of prostitution, of others or other forms of sexual exploitation, forced labor or services, slavery or practices similar to slavery, servitude or the removal of organs ${ }^{11}$. This crime continues to exist and is growing day by day in the world. But measure the extent of illegal activities is a difficult task in itself. Both the International Organization for migrants that the office of the US State Department responsible for monitoring and combating human trafficking highlighted the paucity of data on it. However, the situation changed in 2006 with the boom in transnational trafficking. And when added estimates for internal trafficking (either within the same country) the number of victims is in the millions of people.

Social disparities, underlying political and economic in many developing countries are facilitating the act. Poverty, unemployment, lack of education and professional skills, political oppression and civil disorder are some of the factors that disenfranchise people who are victims. All of those facts making easy the job for organized criminal groups. Most of the victims of this kind of economic exploitation are women and children, who are forced to engage in illegal activities such as forced labor and slavery, prostitution and servile marriage. Indeed, the fight against this scourge is a priority at national and international level. Texts were set up to fight against this scourge and protect all the main victims.

Nationally, Madagascar for its part, is involved in the fight against human trafficking by adopting legal norms. Thus, under Law No. 2007-038 of 14 January 2008 amending and supplementing certain provisions of the Penal Code on the fight against human trafficking and sex tourism, integrates into its legislation penalties for this offense. In this regard, the Penal Code provides the following major offenses: all forms of trafficking, sale, kidnapping and exploitation of people. Internationally, additional agreements and protocols have been adopted by the UN General Assembly on 18 November 2000: The United Nations Convention against Transnational Organized Crime (UNTOC) entered into force on 29 September 2003. Two protocols complement this Convention:

1. The Protocol to Prevent, Suppress and Punish Trafficking in Persons, especially Women and Children (the Protocol against Trafficking in Persons) entered into force on 25 December 2003, of which Madagascar is a member by Decree No. 2005-021 of 17 January 2005 and Law No. 2004-042 of 14 January 2005.

2. The Protocol against the Smuggling of Migrants by Land, Sea and Air (the Protocol against the Smuggling of Migrants), which entered into force on 
28 January 2004.

Under this protocol, the signatory countries must prevent and combat trafficking in persons, undertaking to criminalize the organization, assistance or participation in trafficking in persons in accordance with what is defined in Article 3 (a). They must also prevent and combat the problem by trying to develop research, information campaigns and media campaigns and social and economic initiatives to prevent and combat trafficking in persons. The protocol promotes the exchange of information between states and the training of workers involved in one way or another in the fight against trafficking in human beings (Article 9 and 10).

The Protocol against Trafficking in Persons also contains other provisions on assistance and protection for victims.

\section{b. The torture}

The torture acts are also part of the scope of international cooperation in criminal matters. Madagascar, under Decree No. 2005511 of 3 August 2005 and Act No. 2005-003 of 3 August 2005 on the authorization to ratify the United Nations Convention against Torture is among the members of the Convention against torture and Other cruel, inhuman or Degrading. Indeed, under Article 9 paragraph 1 of this Convention, States Parties shall afford one another the widest measure of mutual assistance in criminal proceedings relating to acts of torture, including in relation to the disclosure of all the evidence they have and that are necessary for the procedure.
The Torture constitutes an act of physical integrity of the victim. It may occur during multiple occasions especially in terms of organized crime such as trafficking for forced prostitution or forced labor. Recalcitrant victims or persons that impede the realization of these criminal actions may undergo torture. The tortures are to be imposed on the body of the victim of continuous acts of violence in order to make it feel as much pain as possible, without killing it right away. So it is to go after the body of the victim to hurt him. Faced with these inhuman treatments, States cooperate in order to track down the perpetrators who are trying to shirk their responsibility. Then the active intervention of public authorities in each state.

\section{B. The Authorities Involved}

The application of judicial cooperation in criminal matters requires the fulfillment of certain conditions not only on the formalities of the application, but also the determination of the competent authorities in the matter. Therefore, the applicant must state authorities to the competent authorities of the requested State in fulfilling the request for assistance. To this end, the international conventions in this field determine the authorities to be entered in the transmission and execution of a request for assistance. They are of two kinds: the political authorities and the judiciary.

\section{The required authorities}

These are the political authorities and the judiciary. 


\section{a. The political authorities}

These are mainly the Minister of Justice as well as diplomatic and consular agents.

\section{1) The minister of justice}

The Minister of Justice is the central authority responsible and the power to receive the request from the foreign state of mutual legal assistance or extradition and presents national applications to them. This specific power is explained by the fact that the Minister of Justice is the highest authority of the judiciary. It ensures this, respect for the law enforcement in the country and actively participates in criminal justice matters internationally. In general, agreements, whether bilateral or multilateral, put the primordial place of the Minister of Justice for international judicial relations. Therefore, the French-Malagasy cooperation of 4 June 1973 Annex -I on self-helpcourt stipulated in Article 7 that: "Pleadings and court decisions to be notified to the persons who are in the territory of one of the two states are addressed directly by the Ministry of Justice of the requesting State at the Department of the State." This provision is also included in Article 8 paragraph 1 in his extradition on the same text.

For other countries, it should be noted also that comparative law including the Convention of the European Union of 1959 on criminal assistance and extradition requires referral to the Minister of Justice of the request of the commission. Therefore, despite some exceptions raised in the convention, countries like Ireland and Sweden do not accept communications or transmissions of letters rogatory directly between the foreign judicial authorities and the Irish judicial authorities, even in cases urgent. In these countries, the Ministry of Justice of the requesting Party will have to apply to the Ministry of Foreign Affairs. And it will enter later the Minister of Justice for the application or the transmission of judicial acts.

In addition, it should be noted that in terms of transnational organized crime, Malagasy law confers jurisdiction in favor of diplomatic agents for the transmission of the request for mutual legal assistance.

\section{2) The consular agents}

From the outset, diplomacy is the science and practice of relations between States. Indeed, the maintenance of diplomatic relations on behalf of his country and represent it with a foreign nation in political, economic and legal. In the latter area, diplomatic agents play an important role in the transmission of judicial documents. It should be noted that these missions of diplomatic agents are regulated by Article 3 of the Vienna Convention of 18 April 1961 on Diplomatic Relations.

Furthermore, the Malagasy Law No. 2004020 of 19 August 2004 on money laundering, screening, confiscation and International Cooperation in proceeds of crime, and in accordance with the recommendation of the United Nations Convention on the lute against transnational organized crime in particular 
in Article 18 paragraph 13 on mutual legal assistance requires the transmission through diplomatic channels to a request for assistance made by foreign authorities for violations determined by the aforementioned UN conventions.

So, the Article 55 of the Act provides: "Requests by foreign competent authorities for the purpose of establishing laundering offenses for the purpose of carrying out or ordering provisional measures or confiscation, or for purposes of extradition are transmitted through diplomatic channels." As for consular officials, the Vienna Convention of 24 April 1963 on Consular Relations signed by Madagascar is explicit. Under its Article 5-j: "consular officers have the task of transmitting judicial and extrajudicial documents or executing letters rogatory in accordance with international agreements in force or, failing such agreements, in any way consistent with the laws and regulations of the State of residence." Finally, it is appropriate to point out that judicial cooperation in criminal matters is not only the work of the political authorities, but it also has the involvement of the judiciary.

\section{b. The judiciary authorities}

In the judicial, there are: first the intervention of the Public Ministry and second the International Criminal Police Organization.

\section{1) The public ministry}

This is "the set of professional judges who are responsible for requesting the application of the law and safeguard the general interests of society." 12 The prosecution is a state body responsible for representing the state, exercising penal action and defending the interests determined by law. Crown attributions cover different areas such: the exercise of criminal action, including the conduct of the criminal investigation.

Moreover, it is the authority which is the first to know of the existence of an offense within the society. Therefore, in the context of international judicial cooperation, the Public Ministry (as the authority responsible for the prosecution) is the decision maker to initiate the request for assistance to the foreign jurisdiction. For the proper functioning of the criminal procedure, this demand is through the Minister of Justice. If extradition request foreign authorities such as the Minister of Justice, accept or reject the request after consultation with the Public Ministry. Moreover, the same article of the aforementioned law provides, in an emergency, the request for assistance and extradition can be direct communication with foreign authorities to the judicial authorities of Madagascar, by mail or by any other means of faster transmission. 
2) The international criminal police organization

The International Criminal Police Organization (ICPO) is an intergovernmental organization whose primary purpose is to facilitate cooperation between police forces around the world. Under Article 2 of its Statute, ICPO actively participates in international mutual assistance in criminal matters. To this end, the organization enables cooperation between Member States in search of individuals for their extradition or surrender of property crime in her country of origin. This is why it occurs particularly when it comes to international delinquency case, that is to say when the action of offenders has continued in the territory of several countries. As soon as the police or any other competent authority of a country is aware of a theft or embezzlement of public deposit for example, and that investigators have reason to believe that these issues will be property sent abroad, the National Central Bureau of Interpol of a country can send a message, giving the information relating to the disputed items wanted or for the purposes of seizure or confiscation, the countries likely to see their territory used as a transit or resale.

Besides, it would be necessary also be noted that the law 2004-020 of August 19 2004 screening laundering, confiscation and International Cooperation in proceeds of crime, in its Article 55 stipulates that in case of emergency, demand for establishing laundering offenses for the purpose of carrying out or ordering provisional measures or confiscation, or for extradition can be a communication through the International Organization for Criminal Police. It follows from the above that the above mentioned authorities are key players in the implementation of international cooperation in criminal matters. Their interventions depend on the running of cooperation and hence the result to the objective of the fight against international crime.

\section{Foundations of their interventions}

The intervention of the authorities can be attributed to various reasons. The aforementioned authorities intervene because they are on one side, the big makers at the state level or on the other hand, the great leaders of the fight against crime at the national level.

\section{a. Reasons drawn from the same quality of the authorities}

The authorities involved are Diplomatic Agents, the Minister of Justice, the Public Ministry, and the International Organization of the International Criminal Police. These are on one side or the other are those that have an important place for the security of the country, or those who do their bidding.

\section{1) Justification by highest official function}

The Minister of Justice is the member of the Government who, among its tasks, the obligation to ensure the correct application of the law, or the existence of the rule of law. 
The Minister of Justice is the guarantor of a good justice. And saw his supervisor position of other members of the repressive arsenal its decision is only very capital. Diplomatic agents are those called by their accreditation in a country to represent the State of origin. Also, about a case involving a state, its involvement in the process is inevitable. By itself, the diplomatic agent is a territory. But here, collaboration request is sent to a territory of another country. Also, its intervention is unavoidable it because he represents his state.

\section{2) Justification by execution}

As for the prosecution, it is he who is responsible for the prosecution of violations of the criminal laws of his country. Since this is a hierarchical body, the execution of the top or by the Minister of Justice returns to his status. Also, for those applications relating to the application of the criminal law, the intervention of the Public Prosecutor is inevitable. It is he who is the guarantor of the respect of criminal laws and represents the whole of society in the context of the prosecution or the enforcement of sentences. So he is the most able to learn about the commission of the unlawful act and respond to the request. Finally, the police agencies internationally are those whose task is useful for searching for criminals or the execution of acts of cooperation.

\section{b. The implementation of actions}

From the outset, remember that the reason be the intervention of the authorities is to actively promote international research and the arrest of fugitive criminals no matter where they hide. This phase aims to stop a person sought and prevent it from escaping before the extradition process could not be implemented. It should be noted that this phase is performed at the stage of pre-extradition, that is to say, during the preliminary phase of the formal extradition request, which begins with the sending, by the pathway required by the Convention, the extradition application with all necessary parts. Therefore, on receipt of a wanted notice, the police authorities can directly decide the implementation of certain measures such as the location of the individual, control and identification, custody, the examination, under surveillance. In most states, the execution of more severe measures is related to the existence of a commission issued by a magistrate: this is the case, for example, of the detention but also provisional seizure of property, documents, and restrictions on freedom of movement.

In this case, the use of the ICPO channel is usually as follows:

First, the international broadcast requests a warrant by a magistrate or the public prosecutor at the National Central Bureau of the State; 
Second, the distribution of a general search warrant by the Interpol network to all or part of the National Central Bureaus or transmitted to the General Secretariat of the National Central Bureau of a request for "Interpol Notice"13 then published to all Offices national Central after review and control by the General Secretariat;

Finally, disseminationmadeby the National Central Bureaus and the Interpol notice or the wanted poster in the relevant state services. Indeed, if discovered; the National Central Bureau of the State where the individual was located informs the General Secretariat and the National Central Bureau applicant who then notifies the magistrate who issued the arrest warrant. Moreover, we have said before, the intervention of these authorities may also consist of the confiscation of proceeds of crime. The rationale of international cooperation among judicial assistance is not only looking for the criminal author for his extradition, but especially to facilitate the seizure and confiscation of proceeds of crime for their return to their country origin.

Therefore confiscation means; "the permanent deprivation of property by order a court or other competent authority." ${ }^{\text {"14 }}$ The Article 13 of the UN Convention on the fight against transnational organized crime deals with international cooperation on confiscation. Indeed, under paragraph 1 of this article, by the request of the competent authorities of the
State party for the confiscation of property and proceeds of crime, the requested State shall forward the request to its competent authorities for the purpose of obtaining a confiscation. It was found that, increasingly, international judicial cooperation in criminal matters is necessary. For by this cooperation, states are trying to help each other to better track criminals. Without limit, the scope of this cooperation includes even fairly large areas. And that cooperation is effective and regular, it requires the intervention of some state authorities, which will thus perform acts of cooperation as outlined in the agreement.

\section{Conclusion}

The fight against transnational crime requires primarily a collaboration of all States. But this requires the will on the part of each State. Madagascar like any other country in the world has signed since its independence, a Judicial Cooperation Agreement to deal with any kind of legal constraint internationally. Given the principle of souvereignty in which each state has a monopoly to administer justice on its territory, it becomes difficult to fight against impunity, without creating a common legal edifice of judicial cooperation through an agreement international. In order to have more chances to fight against organized crime, a large-scale union is imperative. This great union is placed at the United Nations.

At present, most of the world's

13 An Interpol notice is an international alert used by police to communicate information about crimes, criminals and threats to their counterparts around the world. They are circulated by Interpol to all member states at the request of a member or an authorized international entity, by http://en.wikipedia.org/wiki/.

14 Definition to the Article 2-g of the United Nations Convention Against Transnational Organized Crime. 
states, gathered at the United Nations has consciousness of the need to organize globally to try to fight the criminals. Because with the current globalization, crime knows no borders and is also globalized. And the modernization and galloping technological progress, criminals could escape more easily from criminal responsibility. Thus, judicial cooperation, mainly aims to fight a State becomes a place of refuge for offenders who have committed crimes in another state. In fact, the cooperation is a strategy that aims to curb impunity. Therefore: the prerequisite for the establishment of justice. But to achieve effective cooperation, it is necessary that each country shows its resolution to fight together against crime through cooperation. It is only at this price that the world can hope to overcome the cunning criminals at regional level. However, before the requirement of the will of the leaders, it also proves important to improve the domestic law of each member country to avoid problems such as on the principle of double criminality. In short, the idea of judicial cooperation is the only way to establish true justice in the world.

\section{REFERENCES}

\section{Books}

Raymond Guillien, Jean Vincent, Serge Guinchard, Gabriel Montagnier, 2007, Lexique des termes juridiques (ed. Dalloz), 16th Edition, Papier, Toulouse. World Ministerial Conference on Organized Transnational Crime, 1994, Report Of The Ad Hoc Committee On The Elaboration Of A Convention Against Transnational Organized Crime On The Work Of Its First To Eleventh Sessions.

\section{Conventions and International Agreements}

Cooperation Agreements signed in Paris June 4, 1973 between the Malagasy Republic and French Republic.
International Convention for the Suppression of the Financing of Terrorism 1999.

Additional Protocol to the UN Convention against Transnational Crime in 2000 organized to Prevent, Suppress and Punish Trafficking in Persons,Especially Women and Children.

United Nations Convention against Corruption of 31 October 2003.

African Unity Convention on the Prevention Action against Corruption.

OAU Convention on the Prevention and fight against terrorism (Addis Ababa on 8 July 2004).

\section{Texts of Laws}

ACT of 10 March 1927 relating to Extradition 
Of Foreigners, (Made applicable to Madagascar by order of 23 June 1927 JOM of 2.7.27, p.640, RTLI).

Act No.2004-030 relating to Code of Criminal Procedure Malagasy.

LAW No. 2003-017 OF 27 AOUT 2003 Authorizing The Ratification Of The International Convention Of The Oau On The Prevention And Fight Against Terrorism.

LAW No. 2003-019 OF 27 AOUT 2003 Authorizing The Ratification Of The 1997 Convention For The Suppression Of Terrorist Bombings.

LAW No. 2004-017 of 19 August 2004 Authorizing the ratification of the UN Convention against Corruption in Madagascar.
LAW No. 2004-018 of 19 August 2004 Authorizing The Ratification Of The Convention Of The African Union On The Prevention And Fight Against Corruption In Madagascar.

LAW No. 2004-041 of 14 January 2005 Authorizing The Ratification Of The Additional Protocol To The Un Convention Against Transnational Organized Crime Against The Illicit Manufacturing Of And Trafficking In Firearms, Their Parts And Components And Ammunition.

\section{Internet}

Djillali Hadjadj, 2002, Law, Transparency International, www. books.google.fr/ book/365. 